\title{
Identification of a Marine Green Alga Percursaria percursa from Hypersaline Springs in the Middle of the North American Continent
}

\author{
Kathleen L. Londry ${ }^{1}$, Pascal H. Badiou ${ }^{2}$, and Stephen E. Grasby ${ }^{3}$ \\ ${ }^{1}$ Department of Microbiology, University of Manitoba, Winnipeg, Manitoba, R3T 2N2 Canada; e-mail: londryk@cc.umanitoba.ca \\ ${ }^{2}$ Department of Botany, University of Manitoba, Winnipeg, Manitoba, R3T 2N2 Canada; e-mail: pbadiou@ shaw.ca \\ ${ }^{3}$ Geological Survey of Canada, 3303 33 ${ }^{\text {rd }}$ St. NW, Calgary, Alberta, T2L 2A7 Canada; e-mail: SGrasby@ NRCan.gc.ca
}

Londry, Kathleen L., Pascal H. Badiou, and Stephen E. Grasby. 2005. Identification of a marine green alga Percursaria percursa from hypersaline springs in the middle of the North American continent. Canadian Field-Naturalist 119(1): 82-87.

The chlorophycean alga Percursaria percursa (Ulvaceae, Ulvales, Chlorophyceae), typical of marine inter-tidal zones, is reported for the first time from hypersaline springs located along the north-western shore of Lake Winnipegosis in Manitoba. Although not usually found inland, . percursa is the dominant member of microbial mat communities that thrive in shallow pools at the outlets of hypersaline springs.

Key Words: Percursaria percursa, chlorophyta, hypersaline, springs, marine algae, Manitoba.

This study was undertaken to characterise the members of microbial mat communities growing in the pools and outflow channels of hypersaline springs in North-Western Manitoba. Studies on the microbial ecology of hypersaline waters has previously been limited to marshes and standing bodies of water such as salt lakes and salt production ponds (Oren 2002), so very little is known about the microbes inhabiting flowing water sources such as springs. Stable hypersaline springs are uncommon, and well-defined springs amenable to scientific study, particularly at low temperatures, are relatively rare. However, these springs can provide important information about the survival of microbes under extreme conditions. They also provide a modern analogue for the extensive microbial mats that characterised life on Earth during the Precambrian.

The highly saline pools, marshes, and saltpans on the northern margins of Lake Winnipegosis, Manitoba, have created a unique ecosystem dominated by organisms characteristic of marine habitats (Patterson et al. 1997). The flora and fauna have been described previously, with plant species composition similar to prairie saltpans (Burchill and Kenkel 1991), and animals that included marine representatives (Chordata, Protozoa, Rotifera, and Arthropoda) (McKillop et al. 1992). The distribution of the vegetation was linked to the salt tolerance of the species (Burchill and Kenkel 1991). It has been suggested (Patterson et al. 1997) that these marine species were transported to the springs area in Manitoba by birds (including Canada Geese) from coastal areas such as Hudson Bay, $700 \mathrm{~km}$ northeast of this site, and the Gulf of Mexico. Colonization of the saline springs could be no sooner than the retreat of the continental ice sheet, which covered the region up until about 10000 years ago. Patterson et al. (1997) show that a saline ecosystem has been in place since at least 5500 years ago. Colonization by marine species occurred soon thereafter (Patterson et al. 1997).

Geochemical and stable-isotope analyses indicate that spring waters originate as meteoric water (Grasby et al. 2000). There was a large influx of glacial meltwater into the underlying bedrock during the Pleistocene, which dissolved the underlying beds of halite $(\mathrm{NaCl})$, sylvite $(\mathrm{KCl})$ and similar salts deposited by evaporation of Devonian seawater. The retreat of ice sheets has released the waters, discharging now as saline springs (Grasby et al. 2000; Grasby and Chen 2005). There are numerous saline springs along the western shore of Lake Winnipegosis (Grasby 2000). Microbial mats have only been observed at springs in the Dawson Bay area (on the north-western shore of the lake), further west along the Red Deer River (Manitoba), as well as springs near Pelican Bay (east of Dawson Bay). These hypersaline springs flow over a saltpan of barren, iron stained surficial material (McKillop et al. 1992). The high salt concentrations severely limit plant growth in the area, and life within the springs themselves is restricted to microorganisms.

\section{Study Site}

The hypersaline springs are located along the western shore of Lake Winnipegosis in North-Western Manitoba. As shown in Figure 1, the springs are in Manitoba, just south and west of Dawson Bay in the northern extent of Lake Winnipegosis. The locations and chemistry of the spring outlets are summarised in Table 1. Water samples were collected and preserved in the field. The water was passed through a $0.45 \mu \mathrm{m}$ filter. Samples for Fe analysis were acidified to $\mathrm{pH}$ $<2$ with ultrapure $\mathrm{NHO}_{3}$. Samples for anion analysis were untreated. Anions were measured by ion liquid chromatography, and Fe by ICP-MS. The salinity of springs studied here, the feature that defines the springs 


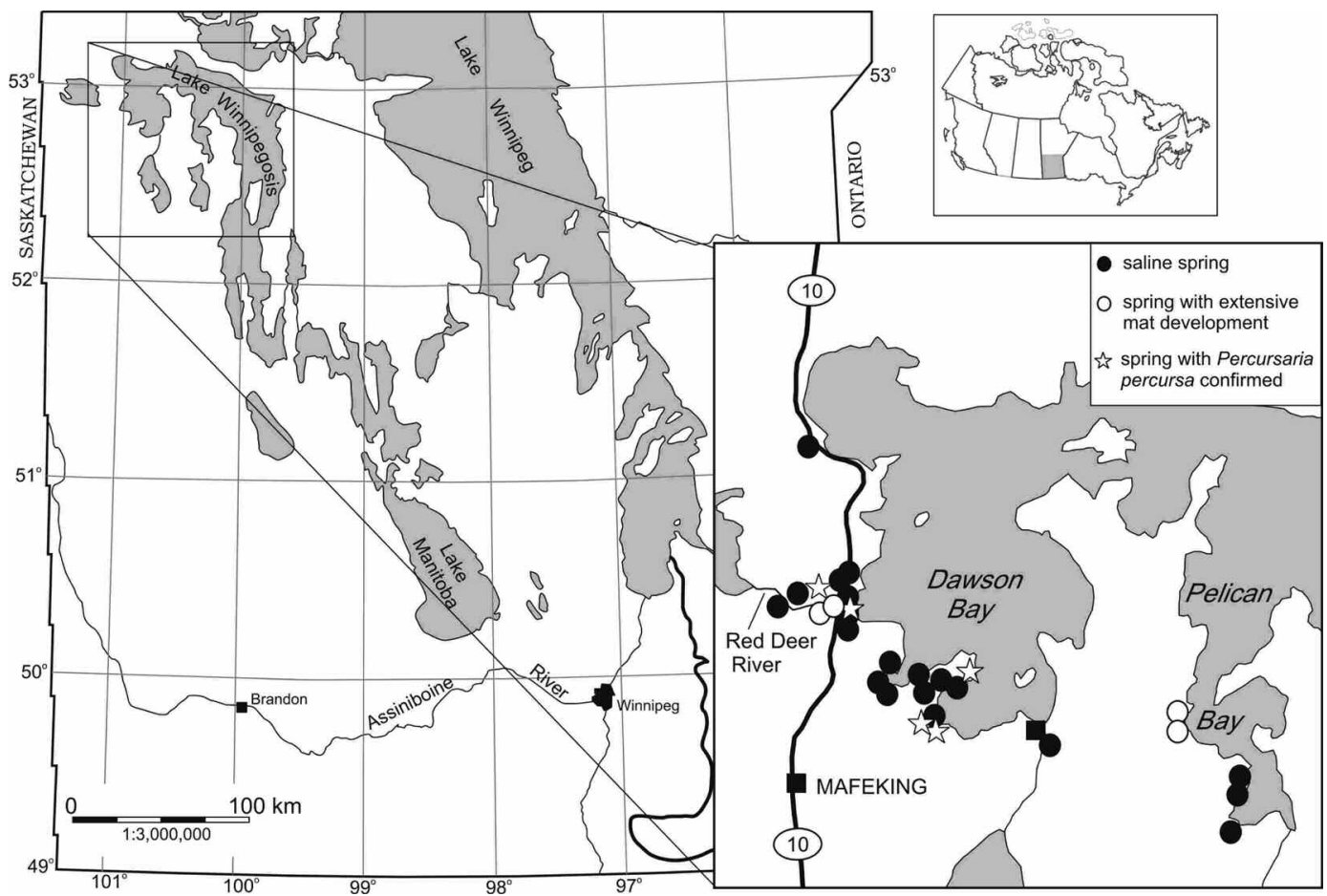

FIGURE 1. Regional map showing locations of saline springs, indicating which ones have been observed to have microbial mats of $P$. percursa.

and limits growth in these areas, ranges from below seawater to twice seawater concentrations. The salinity is mostly from $\mathrm{NaCl}$ (from halite), with minor differences in composition compared to typical seawater. The salt from these springs has been used historically by early settlers (Petch 1987). Chloride and sulfate concentrations in springs containing microbial mats are typically 24 to $36 \mathrm{~g} / \mathrm{l}$ and 2.1 to $3.5 \mathrm{~g} / \mathrm{l}$, respectively (Table 1). Gas bubbles rising from the spring sediments were observed frequently, often becoming trapped by the overlying mat in springs with confluent growth, leading to the appearance of medium to large swellings of the mat fabric. The gas composition is dominantly $\mathrm{N}_{2}(95 \%)$ with traces of $\mathrm{CO}_{2}(1.8 \%), \mathrm{He}(1.5 \%), \mathrm{O}_{2}$ (1.0\%), $\mathrm{Ar}(0.8 \%)$, and $\mathrm{CH}_{4}(0.02 \%)$ (McKillop et al. 1992), with the latter two potentially supporting microbial growth.

Each site consisted of multiple spring outlets, most of which formed pools around the origin, the oldest of which have formed raised cauldrons. Microbial mats grew on the surface and around the margins of the pools (Figure 2). There was considerable red goethite $(\mathrm{FeO} \bullet \mathrm{OH})$ staining in areas surrounding the springs, but not in the spring sources themselves, which are dominated by calcite and quartz. Areas surrounding the springs also sometimes exhibited a characteristic "brainy" texture due to the decomposition of the algal mats beneath the evaporitic gypsum crust. The springs flow year-round and the salinity keeps some of the larger ones from freezing, even in winter (McKillops et al. 1992). Microbial mat growth was observed in freezing temperatures in the fall and spring. Samples of the microbial mats were collected in October 2001, May 2002, and August 2003. Samples were stored on ice or in a freezer $\left(-20^{\circ} \mathrm{C}\right)$ until they were analysed by microscopy at the University of Manitoba using a Leitz Diaplan (Germany) microscope.

\section{Results and Discussion}

\section{Organism}

Percursaria percursa (C. Agardh) Bory De St. Vincent is a green alga of the order Ulvales (Ulvophyceae, Chlorophyta) that is phylogenetically related to Ulva intestinalis (O'Kelly et al. 2004). It forms distinct biseriate simple threads of varying breadth (Bliding 1963). The thalli are typically unbranched, up to $3 \mathrm{~cm}$ long, flexuous and contorted. The double row of cells is usually in exact symmetry (Figure 3), with each cell containing a single parietal band-like chloroplast similar to those seen in species of the genus Ulothrix. Under intense light, the chloroplast forms a narrow parietal girdle in the middle of the cell, whereas under low light levels the chloroplast becomes well developed and less band-like (Bliding 1963). The number of pyrenoids in the chloroplasts of P. percursa varies between one and three with most specimens typically 
TABLE 1. Locations and physicochemistry of spring waters west of Lake Winnipegosis.

\begin{tabular}{|c|c|c|c|c|c|c|c|}
\hline $\begin{array}{l}\text { sample } \\
\text { number }\end{array}$ & Latitude & Longitude & $\begin{array}{l}\mathrm{TDS}^{\mathrm{c}} \\
\mathrm{mg} / \mathrm{l}\end{array}$ & $\begin{array}{c}\mathrm{Cl} \\
\mathrm{mg} / \mathrm{l}\end{array}$ & $\begin{array}{l}\mathrm{SO}_{4} \\
\mathrm{mg} / \mathrm{l}\end{array}$ & $\begin{array}{c}\mathrm{Fe} \\
\mathrm{ug} / 1\end{array}$ & $\mathrm{pH}$ \\
\hline M993013 $^{a}$ & $52^{\circ} 48.105^{\prime}$ & $100^{\circ} 48.750^{\prime}$ & 64510 & 35700 & 3460 & 1700 & 6.87 \\
\hline M003005 & $52^{\circ} 47.977$ & $100^{\circ} 49.430^{\prime}$ & 63488 & 35300 & 3220 & 1900 & 6.70 \\
\hline M993031 & $52^{\circ} 40.893^{\prime}$ & $100^{\circ} 4.798^{\prime}$ & 61637 & 34300 & 3200 & 1200 & 6.75 \\
\hline M993016 ${ }^{\mathrm{a}}$ & $52^{\circ} 45.086^{\prime}$ & $100^{\circ} 52.926^{\prime}$ & 61327 & 33700 & 3170 & 1100 & 6.50 \\
\hline M993029 ${ }^{b}$ & $52^{\circ} 38.235^{\prime}$ & $100^{\circ} 22.120^{\prime}$ & 61015 & 35400 & 1130 & 1700 & 6.29 \\
\hline M993028 b & $52^{\circ} 41.561^{\prime}$ & $100^{\circ} 21.176^{\prime}$ & 60300 & 33000 & 3170 & 1900 & 6.35 \\
\hline M993027 b & $52^{\circ} 41.259^{\prime}$ & $100^{\circ} 20.988^{\prime}$ & 59404 & 32800 & 3180 & 1100 & 6.70 \\
\hline M993019 b & $52^{\circ} 51.752^{\prime}$ & $101^{\circ} 08.166^{\prime}$ & 58646 & 32500 & 2970 & 2500 & 6.60 \\
\hline M993014 ${ }^{b}$ & $52^{\circ} 47.703^{\prime}$ & $100^{\circ} 51.817^{\prime}$ & 58197 & 32100 & 2990 & 2300 & 6.64 \\
\hline M003003 ${ }^{a}$ & $52^{\circ} 52.103^{\prime}$ & $101^{\circ} 04.169^{\prime}$ & 56545 & 31500 & 2780 & 2000 & 6.78 \\
\hline M993020 b & $52^{\circ} 51.289^{\prime}$ & $101^{\circ} 08.159^{\prime}$ & 55861 & 31300 & 2840 & 2700 & 6.73 \\
\hline M003006 ${ }^{\mathrm{b}}$ & $52^{\circ} 47.919^{\prime}$ & $100^{\circ} 53.118^{\prime}$ & 55855 & 31200 & 2770 & 2100 & 6.56 \\
\hline M993026 ${ }^{\mathrm{b}}$ & $52^{\circ} 51.783^{\prime}$ & $101^{\circ} 05.392^{\prime}$ & 55626 & 31000 & 2820 & $<150$ & 6.34 \\
\hline M983075 $^{\text {a }}$ & $52^{\circ} 52.031^{\prime}$ & $101^{\circ} 03.271^{\prime}$ & 54825 & 31000 & 2800 & 2100 & 6.97 \\
\hline M993011 ${ }^{\mathrm{b}}$ & $52^{\circ} 52.603^{\prime}$ & $101^{\circ} 02.886^{\prime}$ & 54543 & 30200 & 2790 & $<150$ & 7.40 \\
\hline M993025 & $52^{\circ} 45.806^{\prime}$ & $100^{\circ} 52.845^{\prime}$ & 49068 & 27400 & 2600 & $<150$ & 6.99 \\
\hline M003002 ${ }^{\mathrm{a}}$ & $52^{\circ} 52.191^{\prime}$ & $101^{\circ} 05.563^{\prime}$ & 48522 & 27200 & 2400 & 1900 & 6.86 \\
\hline M993037 & $51^{\circ} 37.429^{\prime}$ & $99^{\circ} 58.472^{\prime}$ & 43680 & 22300 & 4590 & $<150$ & 8.35 \\
\hline M983076 $^{\mathrm{a}}$ & $52^{\circ} 52.526^{\prime}$ & $101^{\circ} 02.359^{\prime}$ & 42405 & 23700 & 2100 & 3200 & 7.05 \\
\hline M003004 ${ }^{b}$ & $52^{\circ} 45.266^{\prime}$ & $100^{\circ} 53.429^{\prime}$ & 38566 & 21500 & 2090 & 1000 & 6.91 \\
\hline M993038 & $51^{\circ} 49.099^{\prime}$ & $99^{\circ} 43.493^{\prime}$ & 37208 & 19900 & 3000 & $<150$ & 8.38 \\
\hline M993035 & $51^{\circ} 37.424^{\prime}$ & $99^{\circ} 56.777^{\prime}$ & 37189 & 18900 & 3690 & 240 & 7.99 \\
\hline M993034 & $51^{\circ} 43.390^{\prime}$ & $99^{\circ} 57.692^{\prime}$ & 35856 & 18900 & 3010 & $<150$ & 7.96 \\
\hline M983077 & $52^{\circ} 54.092^{\prime}$ & $101^{\circ} 01.125^{\prime}$ & 32786 & 18500 & 1610 & 1000 & 6.98 \\
\hline M983079 & $52^{\circ} 47.205^{\prime}$ & $100^{\circ} 58.041^{\prime}$ & 32356 & 18100 & 1620 & 110 & 7.88 \\
\hline M983073 & $51^{\circ} 55.587^{\prime}$ & $100^{\circ} 09.384^{\prime}$ & 28857 & 15500 & 2300 & 2400 & 7.39 \\
\hline M993036 & $51^{\circ} 36.570^{\prime}$ & $99^{\circ} 51.542^{\prime}$ & 28765 & 14400 & 3360 & $<150$ & 7.95 \\
\hline M993017 & $52^{\circ} 46.802^{\prime}$ & $100^{\circ} 57.852^{\prime}$ & 23733 & 12700 & 1080 & 340 & 6.48 \\
\hline M983074 & $52^{\circ} 00.408^{\prime}$ & $100^{\circ} 08.480^{\prime}$ & 22319 & 11700 & 1400 & 2300 & 7.40 \\
\hline M993041 & $52^{\circ} 02.191^{\prime}$ & $100^{\circ} 09.754^{\prime}$ & 21648 & 10800 & 2250 & $<150$ & 6.94 \\
\hline M003007 & $52^{\circ} 57.587^{\prime}$ & $101^{\circ} 01.299^{\prime}$ & 21100 & 12100 & 1011 & $<150$ & 6.87 \\
\hline M993032 & $51^{\circ} 53.731^{\prime}$ & $100^{\circ} 09.068^{\prime}$ & 20096 & 10300 & 1500 & $<150$ & 5.98 \\
\hline M993021 & $52^{\circ} 43.719^{\prime}$ & $100^{\circ} 40.582^{\prime}$ & 18236 & 9970 & 899 & $<150$ & 7.62 \\
\hline M993033 & $51^{\circ} 50.039^{\prime}$ & $100^{\circ} 07.305^{\prime}$ & 17453 & 8320 & 1580 & $<150$ & 7.84 \\
\hline M993022 & $52^{\circ} 42.632^{\prime}$ & $100^{\circ} 41.958^{\prime}$ & 16946 & 9730 & 808 & $<150$ & 7.10 \\
\hline M993039 & $51^{\circ} 48.000^{\prime}$ & $99^{\circ} 43.792^{\prime}$ & 14371 & 1400 & 2460 & $<150$ & 7.99 \\
\hline M003001 & $51^{\circ} 34.591^{\prime}$ & $99^{\circ} 41.305^{\prime}$ & 11914 & 5530 & 1790 & 390 & 6.93 \\
\hline M993024 & $52^{\circ} 44.569^{\prime}$ & $100^{\circ} 44.862^{\prime}$ & 7189 & 3720 & 321 & $<150$ & 8.28 \\
\hline M993015 & $52^{\circ} 46.525^{\prime}$ & $100^{\circ} 53.561^{\prime}$ & 5892 & 2850 & 151 & $<150$ & 6.62 \\
\hline M993012 & $52^{\circ} 53.878^{\prime}$ & $101^{\circ} 02.030^{\prime}$ & 5027 & 2490 & 180 & $<150$ & 7.75 \\
\hline
\end{tabular}

${ }^{a}$ Hypersaline springs with $P$. percursa

${ }^{\mathrm{b}}$ Hypersaline springs with algal mats, possibly $P$. percursa

${ }^{\mathrm{c}}$ Total dissolved solids (TDS)

having two (Celan 1979). Although the thalli are usually biseriate, it is common to find some thalli that are uniseriate in part. Cells in the material collected from the saline springs bordering Lake Winnipegosis are a typical size (Abbott and Hollenberg 1976), between $10-18 \mu \mathrm{m}$ wide and $24-28 \mu \mathrm{m}$ long. The thalli are light green because of the chloroplasts, but the cells from this site are often covered by amorphous rustcoloured clusters that can impart a brown, to rust, to orange, to red colour to the mats as a whole. This has led to the illusion that these mats are dominated by red and green algae (Bezys et al. 1997; Wadien 1984), when in fact only green algae (Chlorophyta) are present.

This species is usually found with other algae, frequently forming floating entangled masses (often called green tide or sea lettuce) in upper tidepools and salt marshes. In North America, this taxon is found along the Pacific coast (Abbott and Hollenberg 1976; Setchell and Gardner 1920, Garbary et al. 1985), the Atlantic coast (South 1984; Wynne 1986), and in the Arctic (Setchell and Gardner 1920). Typically a marine organism, there is one previous report that $P$. percursa may also occur inland in environments where salt concentrations are elevated (Kornmann 1956). Although reported in many locations, this filamentous alga usually does not occur in large quantities, and is generally a minor contributor to blooms dominated by closelyrelated species of Cladophora and Enteromorpha (Hayden and Waaland 2002; Setchell and Gardner 1920; Taylor et al. 2001). In the hypersaline springs 


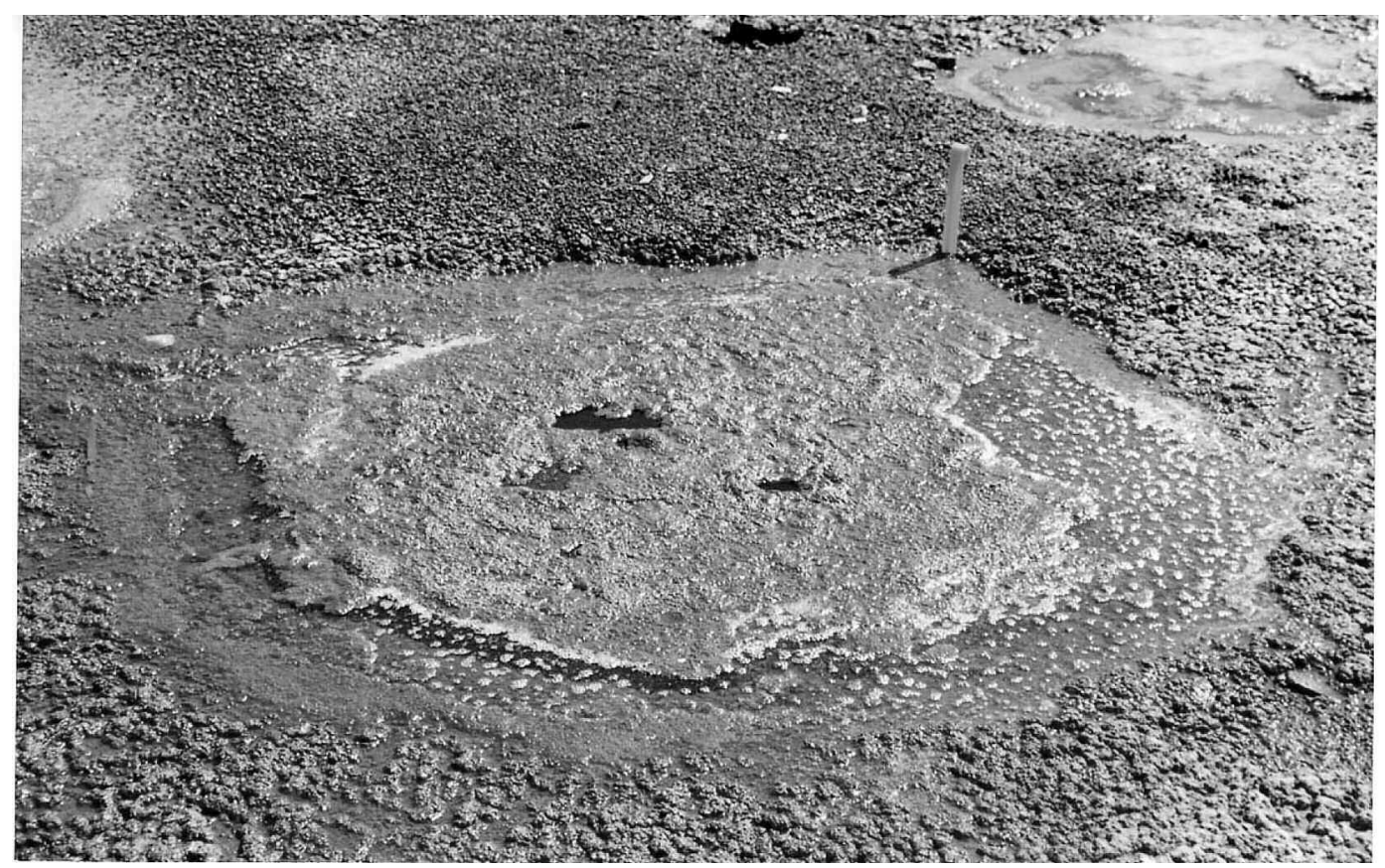

FIGURE 2. Photograph of a hypersaline spring containing extensive mats of $P$. percursa. A $15 \mathrm{~cm}$ tent peg inserted beside the spring is included for scale.

near Lake Winnipegosis, it was by far the dominant organism, associated with various pennate diatoms and cyanobacteria (including members of the Oscillatoriaceae) (unpublished data) but not other filamentous green algae.

\section{Habitat and distribution}

There are numerous saline springs along the western shore of Lake Winnipegosis (Grasby 2000; Bezys et al. 1997; McKillop et al. 1992) as well as in north-eastern Alberta (Grasby and Chen 2005), however, prolific growth of $P$. percursa has only been confirmed at the Dawson Bay salt springs located on the north-western shore of the lake. Similar algal growths have been observed at other sites west of Pelican Bay and south of Red Deer River, but detailed analyses have not been done to confirm P. percursa. Salinity at these sites is typically greater than that of the springs located further south in Manitoba, and this may explain the dominance of $P$. percursa. The salinity of the springs is thought to be increasing over time (Patterson et al. 1997), and although the full range salinity tolerance is unknown, it does not seem to be limiting growth of this organism, but rather promoting it. $P$. percursa can grow in diluted seawater over a range of 0-34 PSU (practical salinity units), with an optimum of 24 PSU (Taylor et al. 2001), but tolerance above seawater has not been tested. . percursa has a broad tolerance to environmental conditions of irradiance $(9-175 \mu \mathrm{mol}$ $\mathrm{m}^{-2} \mathrm{~s}^{-1}$ ) and temperature (at least $10-30^{\circ} \mathrm{C}$ ), as well as

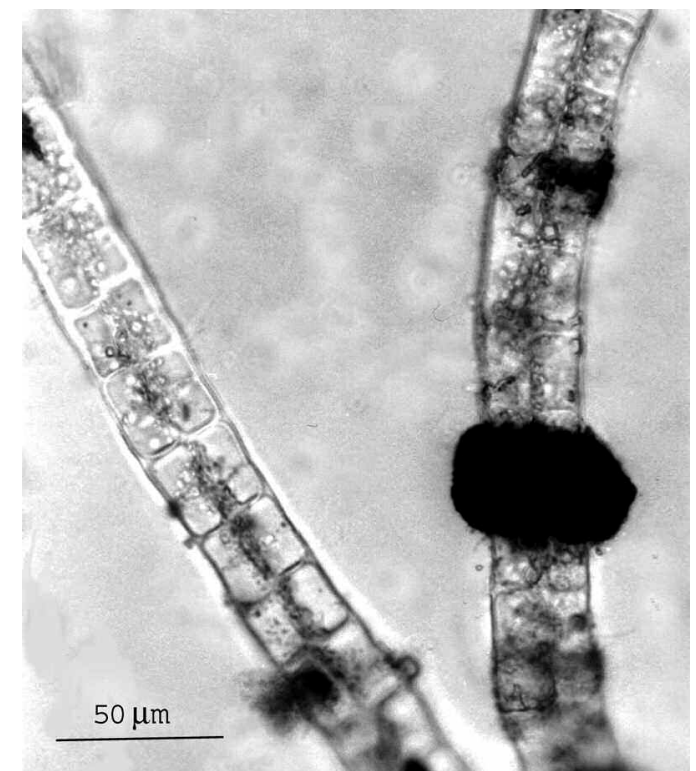

FIGURE 3. Photomicrograph (1000x) of filaments of Percursaria percursa from a hypersaline spring west of Lake Winnipegosis. The biseriate cells are paired in two longitudinal rows in each filament. Note the large accumulation of material on the right strand that imparts a rust-red color to the mats as a whole, although the filaments themselves are green. The scale bar represents $50 \mu \mathrm{m}$. 
$\mathrm{N}$ and $\mathrm{P}$ concentrations [1-200 $\mu \mathrm{M} \mathrm{PO}_{4}{ }^{3-}, 10-1000 \mu \mathrm{M}$ $\mathrm{NO}_{3}^{-}, 1-100 \mu \mathrm{M} \mathrm{NH}_{4}^{+}$] (Taylor et al. 2001). Growth of "green tide" algae like $P$. percursa is generally enhanced by eutrophic conditions, but the springs west of Lake Winnipegosis are pristine discharges, with the only potential sources of significant amounts of $\mathrm{N}$ and $\mathrm{P}$ from sporadic incidences of bird defecation.

The distribution of $P$. percursa was compared to water chemistry parameters by principle component analysis (PCA) using The Unscrambler ${ }^{\circledR}$ 7.6, a multivariate statistical software package. The first two axes of the PCA explained $86 \%$ of the total variance and revealed differences in the water chemistry between hypersaline springs with and without mat communities (Figure 4). PCA axis 1 explained $65 \%$ of the total variation between the springs and clearly separated hypersaline springs with mat communities from those without. Total dissolved solids (TDS $=$ the sum of major cations and anions) and chloride explained 95.2 and $94.6 \%$ of the variance in the scores of the hypersaline springs on axis 1, respectively. All hypersaline springs with mat communities were situated to the right of axis 1 and positively correlated to TDS and chloride, indicating that high salinities are required for the growth of P. percursa. Iron and sulphate concentrations also appeared to be correlated to the presence of mats and explained 49.0 and $56.5 \%$ of the variance on axis 1, respectively. Additionally, PCA axis 2 explained $21 \%$ of the variation between the hypersaline springs. On this axis $\mathrm{pH}$ was the most important factor, explaining 55.3\% of the variance on axis 2 , and indicated that the growth of $P$. percursa occurred in springs with lower $\mathrm{pH}$.

In addition to the above parameters, other factors must also determine the distribution, as not all springs at each site contain mats of $P$. percursa. The temperature of the waters varied seasonally, ranging from $5^{\circ} \mathrm{C}$ (temperature of the source water) up to $30^{\circ} \mathrm{C}$ in the summer, but densities did not correlate with temperature. Growth of the organism is restricted to springs with high flow rates that form open pools, and it is not observed in low-flowing seeps in the area even if the water chemistry is compatible. In addition, distinct pools or cauldrons just a few meters apart, or even touching, had extensive growth of mats in one pool and nothing in the other. Considering the motility of the species, and its widespread distribution in the area, lack of colonization would not explain the patchy distribution. There could be a subtle difference in the chemistry of the water at each outlet, although chemical measurements to date indicate that all the water from these sites originates from the same source. There could be a difference in predation to explain the disparity of mat development in different springs. Studies

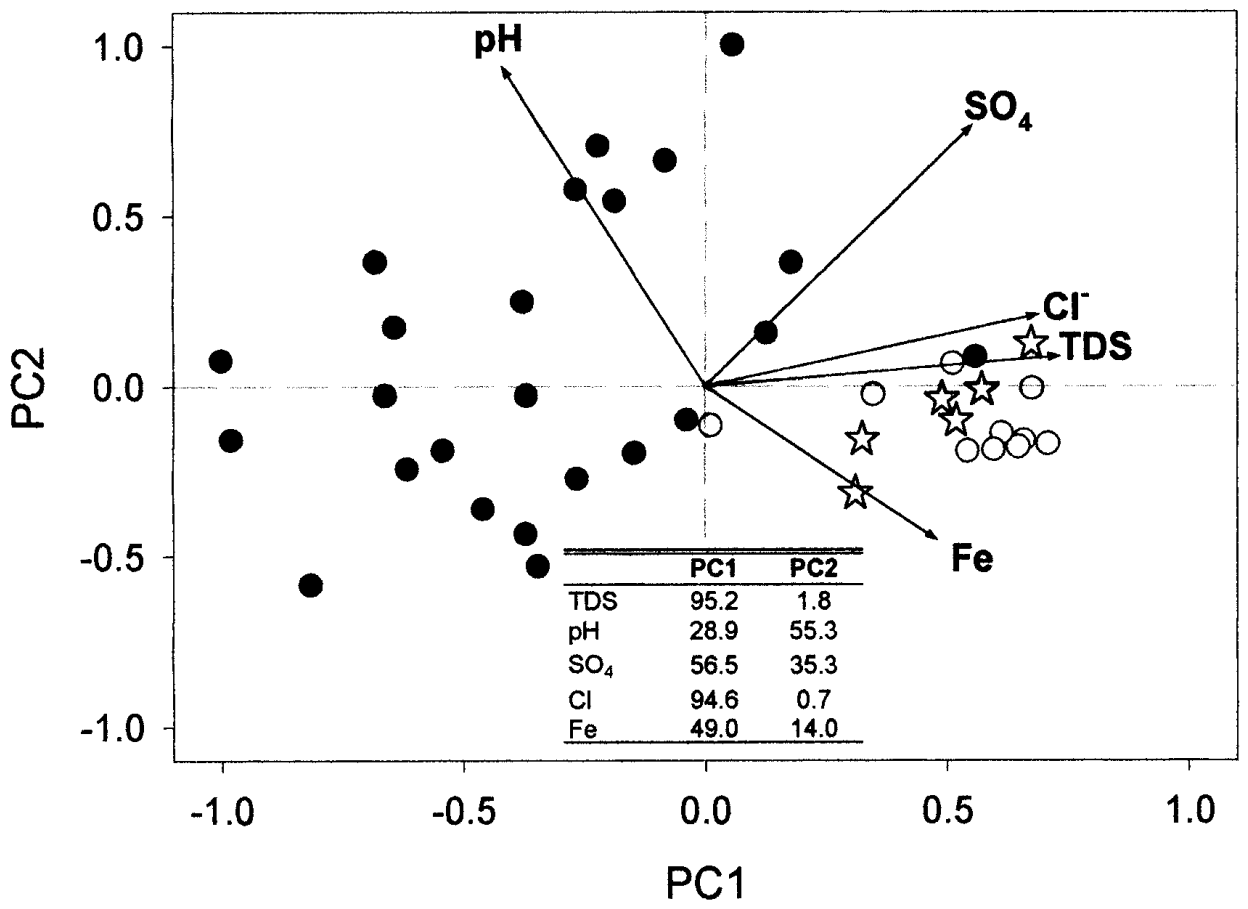

FIGURE 4. Principle component analysis (PCA) ordination biplot displaying grouping of hypersaline springs with respect to water chemistry. The symbols represent springs without $P$. percursa (closed circles), with mat communities not yet confirmed as $P$. percursa (open circles), and with confirmed mats of $P$. percursa (open stars). The inset table lists the relative contributions (in \%) of each chemical parameters to the variance on each of the two axes. 
of rotifer populations in areas containing $P$. percursa found that this predator is limited by high salt concentrations as well as higher temperatures (SaundersDavies 1998). The dynamics of growth and predation require further study at this site.

\section{Further research}

The ability of $P$. percursa to grow and thrive in this extreme environment certainly merits further scientific investigation. The extent to which this dominant primary producer supports an entire ecosystem of microbes in the mat community is the subject of ongoing research. This organism supports a dynamic community of anaerobes including sulphate-reducing bacteria and methanogens. The potential for methanogenic fermentation of $P$. percursa biomass at lower salinities has been demonstrated previously, and proposed as a future mechanism for the production of a renewable source of biogas (Schramm and Lehnberg 1984). The extent to which this organism affects the precipitation and mineralization of carbonates (calcium carbonate) and iron (hematitic- to limonitic) at these sites (Bezys et al. 1997), causing the distinctive reddish brown sinter or tufa mounds of springs on the salt pans, also requires further investigation. These mats also likely support a unique community of invertebrates and epiphytic algae, which to date have not been investigated to our knowledge.

\section{Acknowledgments}

This research was supported by NSERC. Thanks to K. Dawson, H. Grover, and S. Mohammed for collection of samples. Thanks to H. Kling at the Freshwater Institute (Winnipeg, Manitoba) for helpful advice regarding the identification of $P$. percursa.

\section{Literature Cited}

Abbott, I. A., and G. J. Hollenberg. 1976. Marine algae of California. Stanford University Press, Stanford, California 844 pages.

Bezys, R. K., E. B. Ducharme, J. D. Bamburak, and M. A. F. Fedikow 1997. A geochemical study of saline brine sediments as a guide to Prairie-type microdisseminated mineralization and other precious metals in west-central Manitoba; Pages 118-122 in Report of Activities 1997, Manitoba Energy and Mines, Minerals Division.

Bliding, C. 1963. A critical survey of European taxa in Ulvales Part I Capsosiphon, Percursaria, Blidingia, Enteromorpha. Opera Botanica 8: 1-160.

Burchill, C. A., and N. C. Kenkel. 1991. Vegetation-environment relationships of an inland boreal salt pan. Canadian Journal of Botany 69: 722-732.

Celan, M. 1979. Deux algues vertes (Chlorophyceés) nouvelles pour le littoral Roumain de la Mer Noire. Cercetari Marine 12: 109-113.

Garbary, D. J., G. I. Hansen, and R. F. Scagel. 1985. Additions to the marine algae of Barkley Sound, Vancouver Island, British Columbia. Syesis 17: 43-45.

Grasby, S. E. 2000. Saline spring geochemistry, west-central Manitoba; Pages 214-216 in Report of Activities 2000,
Manitoba Industry, Trade and Mines, Manitoba Geological Survey.

Grasby, S., K. Osadetz, R. Betcher, and F. Render. 2000, Reversal of the regional-scale flow system of the Williston basin in response to Pleistocene glaciation: Geology 28: 635-638.

Grasby, S. E. and Z. Chen. 2005. Subglacial recharge into the Western Canada Sedimentary Basin - Impact of Pleistocene glaciation on basin hydrodynamics. Geological Society of America Bulletin. 117: 500-517.

Hayden, H. S., and J. R. Waaland. 2002. Phylogenetic systematics of the Ulvaceae (Ulvales, Ulvophyceae) using chloroplast and nuclear DNA sequences. Journal of Phycology 38: 1200-1212.

Kornmann, P. 1956. Zur Morphologie und Entwicklung von Percursaria percursa. Helgoländer Wissenschaftliche Meeresuntersuchungen 5: 259-272.

McKillop, W. B., R. T. Patterson, L. D. Delorme, and T. Nogrady. 1992. The origin, physico-chemistry and biotics of sodium chloride dominated saline waters on the western shore of Lake Winnipegosis, Manitoba. Canadian FieldNaturalist 106: 454-473.

O'Kelly, C. J., B. Wysor, and W. K. Bellows. 2004. Gene sequence diversity and the phylogenetic position of algae assigned to the genera Phaeophila and Ochlochaete (Ulvophyceae, Chlorophyta). Journal of Phycology 40: 789-799.

Oren, A. 2002. Molecular ecology of extremely halophilic Archaea and Bacteria. FEMS Microbiology Ecology 39: 1-7.

Patterson, R. T., W. B. McKillop, S. Kroker, E. Nielsen, and E. G. Reihardt. 1997. Evidence for rapid avian-mediated foraminiferal colonization of Lake Winnipegosis, Manitoba, during the Holocene Hypsithermal. Journal of Paleolimnology 18: 131-143.

Petch, V. 1987. The 1986 Survey of salt flats and pools along the western shore of Lake Winnipegosis. Manitoba Archaeological Quarterly 11: 13-22.

Saunders-Davies, A. 1998. Differences in rotifer populations of the littoral and sub-littoral pools of a large marine lagoon. Hydrobiologia 387/388: 225-230.

Schramm, W., and W. Lehnberg. 1984. Mass culture of brackish-water-adapted seaweeds in sewage-enriched seawater II: Fermentation for biogas production. Hydrobiologia 116/117: 282-287.

Setchell, W. A., and N. L. Gardner. 1920. The marine algae of the Pacific coast of North America: Part II. Chlorophyceae. University of California Publications in Botany 8: 272-274.

South, G. R. 1984. A checklist of marine algae of eastern Canada, second revision. Canadian Journal of Botany 62: 680-704.

Taylor, R., R. L. Fletcher, and J. A. Raven. 2001. Preliminary studies on the growth of selected 'Green Tide' algae in laboratory culture: Effects of irradiance, temperature, salinity, and nutrients on growth rate. Botanica Marina 44: 327-336.

Wadien, R. 1984. The geochemistry and hydrogeology of saline spring waters of the Winnipegosis area, southwestern Manitoba; B.Sc. thesis, University of Manitoba, Winnipeg, Manitoba 65 pages.

Wynne, M. J. 1986. A checklist of benthic marine algae of the tropical and subtropical western Atlantic. Canadian Journal of Botany 64: 2239-2281.

Received 5 July 2004

Accepted 25 February 2005 